\title{
POTENTIAL OF CORIANDER SEEDS IN MODULATING SOME PHYSIOLOGICAL, MICROBIOLOGICAL AND PRODUCTIVE RESPONSES IN GROWING JAPANESE
} QUAIL.
Gamal
El-Dien,
Hala
M. ${ }^{1} ; \quad$ Eman
F. El-Daly ${ }^{2}$
and
Nematallah G.M. Ali ${ }^{3}$

1-Poultry Nutrition, Biological and Environmental, Dept., Fac. Of Home Economic, Al-Azhar Univ.

2-Animal and Poultry Nutrition and Production, National Res. Center. Dokki, Giza, Egypt.

3-Poultry Production Dept., Fac. Agric., Ain Shams Univ., Cairo, Egypt.

\begin{abstract}
One hundred and fifty one-day old Japanese quail chicks were used in this study. Birds were classified into equal five groups (each of 30 birds). During the first week, all quail chicks were fed on the same diet, thereafter chicks were distributed into five groups. Four different levels of coriander seed were added to a standard diet to generate other four groups $(0.3,0.6,0.9$ and $1.2 \%)$ for $G_{1}, G_{2}, G_{3}$ and $G_{4}$ respectively, while $\mathrm{G}_{5}$ used as control. At the end of experiment (42 days), 5 quails from each group were randomly chosen and slaughtered. Plasma samples were collected and frozen until biochemical analysis.

Growth performance and carcass traits were also evaluated. Results obtained could be summarized as follow:

1-Body weight, body weight gain and feed efficiency were significantly differed $(\mathrm{P} \leq 0.05)$ and improved by supplementation of coriander seed as compared to control, (4.6, 4.9, $-13.1 \%$ resp.).

2- No significant differences were found between the experimental groups for the carcass traits, but heart, liver and kidney were slight increased by the supplementation $0.6,0.9$ and $1.2 \%$ of coriander.

3-Plasma total cholesterol, and total lipids were not significantly different than the control, although birds that fed on 0.6 of coriander showed a lesser plasma total lipids than the other treatments.

4-Plasma ALT activity showed a slight significant differences for quails fed the coriander seeds than the control, but plasma AST activity was not affected.

5-Plasma total protein concentration and $\mathrm{H} / \mathrm{L}$ ratio were not significantly different by coriander supplementation.

6-Hematocrit showed significantly differences between treatments especially at 0.9 and $1.2 \%$ of coriander supplementation.

7-Birds fed on $0.6,0.91 .2 \%$ of coriander had the lowest counts of bacteria, $(-6.9$, $7.6,-58.5 \%$ resp.).

Therefore, the supplementation of coriander seeds in bird's diets could be recommended to improve the absorption of nutrients in addition to their protective role against the deleterious effects of certain diseases.
\end{abstract}

\section{INTRODUCTION}

Dietary antibiotics have played an important role in animal production as growth and health promoters. However, the use of most antibiotic growth 
promoters has been banned in many countries, especially in the European Union, because of the public concerns about their residues in the animal products and the development of antibiotics- resistant bacteria (Schwarz et al., 2001 and Lee et al., 2004). Consequently, the use of antibiotics in poultry diets has been curtailed and scientists have been searching for alternatives to antibiotics. The aromatic plants and the oils extracted from these plants have become more important due to their potential antimicrobial and stimulating effects in the animal digestive system. Aromatic plants have been used traditionally as antiparasitics, anthelmintic, analgesic, expectorant, sedative, antiseptic and antidiabetic substances in many parts of the world (Lee et al., 2004). In addition, they possess antimicrobial activity, (Elgayyar et al., 2001; Singh et al., 2002; Valero and Salmeron, 2003), biological activities such as that of the antioxidants, which have the capacity to reduce freeradicals formation by scavenging free-radicals and protecting antioxidants defences (Chithara and Leelamma, 1999 and Miura et al., 2002) and hypocholesterolemics, so they can reduce the risk for the development of several chronic diseases such as cancer and heart attack (Craig, 1999). Recent studies have shown that they have a stimulating effect on the digestive system of animals through increasing the production of the digestive enzymes and improving the utilization of digestive products through enhanced liver functions (Langhout, 2000; William and Losa, 2001, and Hernandez et al., 2004). Furthermore, limited research has suggested that some aromatic plants and their components could improve feed intake, feed conversion ratio and carcass yield (Ather, 2000; Bassett, 2000; Hertrampt, 2001 and Tucker, 2000). As coriander (Coriandrum Sativum L.) an aromatic plant, is an annual species of the parsley family, native to the eastern Mediterranean region and Southern Europe, and is found in many other parts of the world. Coriander seeds are used primarily as a flavouring agent in the food industry or as a spice in bread, cheese, Curry, fish meat, sauces, soup, pastries and confections. They are used as a flavouring agent in bread and yield essential oil for the manufacturing of soaps and perfumes. Coriander has been used as a medicine for thousands of years and is still used in folk medicine. As a medicinal plant, coriander has been used to manage diabetes (Swantson - Flatt, 1990 and Gray, 1999), as an antifungal (Basilico and Basilico, 1990), antioxidant (Chithara and LeeLamma, 1999), hypolipidemic (Chithara and LeeLamma, 2000) antimicrobial (Delaquis et al., 2002; Singh et al., 2002 and Elgayyar et al., 2001), hypocholesterolemic (Chithara and Leelamma, 1997) and anticonvulsant (Hossein and Mohammed, 2000) substances. In addition, it has appetizing and stimulatory effects in the digestion process (Cabuk et al., 2003). and antiinflammatory activity (Ammar et al., 1997). However, scanty literature concerning the effect of coriander on animal performance are available. In recapitulation of numerous biological possibilities for supporting immunity by the management the quality of animal products and also by introducing additives into animal feed mixtures or using supplemented diets to create functional feeds. So, it could be said that these mentioned substances may be used for the modification of feed or food quality and health status of animal products. Therefore, the aim of this study is to investigate the potential effects of different supplementation levels of 
coriander seeds as a lipolytic and antioxidant compound on the some physiological and microbiological parameters and the performance of Japanese quail.

\section{MATERIALS AND METHODS}

\section{Experimental birds and management:}

One hundred and fifty one-day old Japanese quail chicks were randomly divided into five experimental groups, each of 30 birds. All quail chicks were fed a diet based on yellow corn and soybean meal during the first week. Thereafter this period, chicks were distributed into five groups, the presence and levels of coriander seeds in diets were the main factor tested, the birds, in the control group $\left(G_{5}\right)$, were fed a standard diet according to NRC (1994). Four different levels of coriander seeds were added to the standard diet to generate the four groups $(0.3,0.6,0.9$ and $1.2 \%)$ for $\mathrm{G}_{1}, \mathrm{G}_{2}$, $\mathrm{G}_{3}$ and $\mathrm{G}_{4}$, respectively instead of the same amount of yellow corn. The diets were prepared to be isoenergetic and isonitrogenous. Diets and water were provided ad libitum. The ingredients and chemical compositon of the diets are presented in Table1.

Table (1): Composition and calculated analysis of the experimental diets of the growing quails.

\begin{tabular}{|c|c|}
\hline Ingredients (\%) & $\%$ \\
\hline Yellow corn & 54.65 \\
\hline Soybean meal $48 \%$ & 32.0 \\
\hline Wheat bran & 5.10 \\
\hline Corn gluten meals $62 \%$ & 4.5 \\
\hline DI- Methionine & 0.11 \\
\hline L- Lysine HCL & 0.195 \\
\hline Vegetable oil & 0.50 \\
\hline Mono - Ca phosphate & 0.825 \\
\hline Premix $^{*}$ & 0.30 \\
\hline Limestone & 1.49 \\
\hline Salt & 0.33 \\
\hline \multicolumn{2}{|l|}{ Calculated analysis } \\
\hline CP \% & 24 \\
\hline ME (Kcal / Kg) & 2900 \\
\hline Calcium \% & 0.81 \\
\hline Av. Phosphorus \% & 0.32 \\
\hline Methionine \% & 0.5 \\
\hline Methionine + Cystine \% & 0.89 \\
\hline Lysine \% & 1.32 \\
\hline EE \% & 3.16 \\
\hline CF \% & 3.07 \\
\hline
\end{tabular}


Measurements:

Growth performance parameters:

The live body weights of chicks at the beginning of the experiment and at weekly intervals were recorded to the nearest gram. Body weight gain was then calculated by subtracting the average live body weight of chicks in a pervious period from a given period being recorded. Feed consumption was weekly recorded for each group and then the feed efficiency ratio was calculated as gram body weight gain to gram feed.

Carcass Traits:

At the end of the experimental period, five birds from each groups were randomly taken, weighed and slaughtered. Feathers were manually removed and birds were reweighed and eviscerated. Carcass weight as well as weights of heart, liver, kidney, gizzard, spleen, and pancreas were also recorded to the nearest $0.01 \mathrm{gram}$.

Blood sampling and chemical analysis of blood parameters:

At 42 days post treatment five quails from each group were randomly chosen and slaughtered. Blood samples were collected in heparinized tubes, centrifuged at $4000 \mathrm{rpm}$ for $15 \mathrm{~min}$., then plasma samples were decanted and stored frozen at $-20^{\circ} \mathrm{C}$ until biochemical analysis were done. While, a drop of blood from each sample was used to make smears for the differential leucocytes counts. Differential counts of 100 leucocytes were made using glass slides stained with Wright's stain, and heterophils to lymphocytes ratio $(\mathrm{H} / \mathrm{L}$ ratio) was determined. Also, a portion of blood was used for hematocrit determination $(\mathrm{Ht} \%)$ using heparinized capillary tubes and microhematocrit centrifuge. The hematocrit figures were used after spinning microhematocrit tubes for $15 \mathrm{~min}$. according to Hunsaker (1969). The concentration of plasma total protein, cholesterol, total lipid, aspartate amino transferase (AST), and alanine amino transferase (ALT) were determined using commercial kits (Diamond Diagnostic), where the biochemical analysis of plasma blood samples were done according to the manufacturers recommendations.

Microbiological examination

Total counts of bacteria, coliforms and salmonella were counted on cecal for quails that fed coriander seeds and control diets. Total count of bacteria had been determined using nutrient agar medium as described of Oxoid (1992). Salmonella was detected according to the method by APHA (1976), and Coliforms was detected according to Refai, (1979).

Statistical analysis :

Data were statistically analyzed by using statistical program SPSS (1997). All data were subjected to statistical analyses of variance and means were compared using Duncan's multiple range test (Duncan, 1955).

\section{RESULTS AND DISCUSSION}

\section{Growth performance :}

The effect of different dietary levels of coriander seeds on body weight, weight gain and feed efficiency are presented in Tables (2 and 3). The birds consuming the diets containing coriander seeds showed higher and 
significant differences $(P \leq 0.05)$ in body weight and body weight gain than those of the control group, (4.6, $4.9 \%$ resp.). The inclusion of coriander seeds in the diets improved the daily live weight as compared to control. Also, feed consumption differed significantly $(\mathrm{P} \leq 0.05)$ for the birds fed on coriander seeds compared to control, (10-13\%). The improvement in the feed consumption with the addition of coriander seeds could be due to the essential oils and their main component, linalool. It has been reported that linalool has an appetizing effect in diets and stimulates the digestive process in animals (Cabuk et al., 2003). Positive effects of essential oils on feed intake have also been reported previously (Ather, 2000; Hertrampt, 2001 and Williams and Losa, 2001). These results are also in agreement also with those of Goyal et al., 1984. Consequently, feed efficiency was significantly improved by the supplementation of coriander seeds as compared to control group.

Table (2): Effect of coriander supplementation on body weight, and body weight gain.

\begin{tabular}{|c|c|c|c|c|c|}
\hline $\begin{array}{l}\text { Groups } \\
\text { Parameters }\end{array}$ & $\mathrm{G}_{1}$ & $\mathrm{G}_{2}$ & $\mathrm{G}_{3}$ & $\mathrm{G}_{4}$ & $\mathrm{G}_{5}$ \\
\hline \multicolumn{6}{|l|}{ Body weight (g) } \\
\hline Initial weight & $15.48 \pm 0.39$ & $15.73 \pm 0.09$ & $16.16 \pm 0.51$ & $15.90 \pm 0.29$ & $15.23 \pm 0.66$ \\
\hline $4 \mathrm{wk}$ & $85.87 \pm 6.15^{\mathrm{a}}$ & $91.4 \pm 5.68^{a}$ & $83.0 \pm 3.29$ & $80.42 \pm 6.58^{\mathrm{a}}$ & $63.86 \pm 3.74^{b}$ \\
\hline 6 wk & $166.67 \pm 12.2^{\mathrm{a}}$ & $165.66 \pm 6.23^{a}$ & $154.80 \pm 5.21^{a}$ & $123.33 \pm 6.01^{b}$ & $159.33 \pm 14.35^{\mathrm{a}}$ \\
\hline \multicolumn{6}{|c|}{ Body weight gain (g) } \\
\hline $0-4$ wk & $70.39 \pm 6.63^{a}$ & $75.67 \pm 6.65^{a}$ & $66.84 \pm 4.81^{a}$ & $64.52 \pm 6.12^{\mathrm{a}}$ & $48.68 \pm 3.51^{\mathrm{b}}$ \\
\hline $4-6 w k$ & $80.80 \pm 6.2^{a}$ & $74.26 \pm 6.21^{\mathrm{a}}$ & $71.80 \pm 5.18^{\mathrm{a}}$ & $42.91 \pm 6.01^{\mathrm{b}}$ & $95.47 \pm 7.89^{\mathrm{a}}$ \\
\hline $0-6 w k$ & $151.12 \pm 11.09^{a}$ & $149.93 \pm 6.1^{\mathrm{a}}$ & $138.64 \pm 5.08^{a}$ & $107.43 \pm 6.02^{b}$ & $144.1 \pm 13.89^{a}$ \\
\hline
\end{tabular}

a,b: Means in the same row with the same letters are not significantly different $(P \leq 0.05)$.

Table (3): Effect of coriander supplementation on feed consumption and feed efficiency.

\begin{tabular}{|c|c|c|c|c|c|}
\hline $\begin{array}{l}\text { Groups } \\
\text { Parameters }\end{array}$ & $\mathrm{G}_{1}$ & $\mathrm{G}_{2}$ & $\mathrm{G}_{3}$ & $\mathbf{G}_{4}$ & $\mathrm{G}_{5}$ \\
\hline \multicolumn{6}{|c|}{ Feed Consumption (g) } \\
\hline $0-4 w k$ & $17.96 \pm 1.9^{a}$ & $20.01 \pm 1.9^{a}$ & $19.89 \pm 1.6^{a}$ & $19.2 \pm 1.8^{a}$ & $16.6 \pm 1.4^{a}$ \\
\hline $4-6$ wk & $27.5 \pm 2.15^{b}$ & $31.2 \pm 2.95^{b}$ & $28.5 \pm 2.1^{b}$ & $18.02 \pm 2.02^{\mathrm{a}}$ & $27.3 \pm 2.24^{b}$ \\
\hline & $22.5 \pm 2.05^{a}$ & $25.5 \pm 2.09^{a}$ & $24.8 \pm 2.04^{a}$ & $18.30 \pm 1.09^{a}$ & $22.4 \pm 2.03^{a}$ \\
\hline \multicolumn{6}{|c|}{ Feed Efficiency $(\mathrm{g} / \mathrm{g})$} \\
\hline $4-6 w k$ & $0.21 \pm 0.01^{\mathrm{b}}$ & $0.17 \pm 0.01^{\mathrm{a}}$ & $0.18 \pm 0.01^{a}$ & $0.17 \pm 0.01^{\mathrm{a}}$ & $0.25 \pm 0.02^{b}$ \\
\hline $0-6 w k$ & $0.24 \pm 0.02^{\mathrm{a}}$ & $0.21 \pm 0.02^{\mathrm{a}}$ & $0.20 \pm 0.01^{a}$ & $0.21 \pm 0.01^{\mathrm{a}}$ & $0.23 \pm 0.01^{\mathrm{a}}$ \\
\hline
\end{tabular}

$a, b$ : Means in the same row with the same row with the same letters are not significantly different $(P \leq 0.05)$.

\section{Carcass Traits :}

Effect of different levels of coriander seeds supplementation on some organs are shown Table (4). No significant differences were found between treatments but, heart, liver and kidney were slightly increased by coriander supplementation especially at levels of $0.6,0.9$ and $1.2 \%$ and these results are in agreement with the finding of Guler et al., (2005). 
Gamal EI-Dien, Hala M. et al.

Table (4): Effect of coriander supplementation on carcass traits.

\begin{tabular}{|lccccc|}
\hline Garameters & $\mathbf{G}_{1}$ & $\mathbf{G}_{\mathbf{2}}$ & $\mathbf{G}_{\mathbf{3}}$ & $\mathbf{G}_{\mathbf{4}}$ & $\mathbf{G}_{\mathbf{5}}$ \\
\hline Live body weight $(\mathrm{g})$ & $167.63 \pm 15.6^{\mathrm{a}}$ & $172.25 \pm 11.8^{\mathrm{a}}$ & $161.08 \pm 12.7^{\mathrm{a}}$ & $148.85 \pm 13.9^{\mathrm{b}}$ & $140.25 \pm 14.9^{\mathrm{b}}$ \\
Heart \% & $0.75 \pm 0.004$ & $0.92 \pm 0.009$ & $0.73 \pm 0.008$ & $0.74 \pm 0.005$ & $0.81 \pm 0.005$ \\
Liver \% & $3.24 \pm 0.05^{\mathrm{a}}$ & $3.01 \pm 0.08^{\mathrm{a}}$ & $4.43 \pm 0.006^{\mathrm{b}}$ & $2.58 \pm 0.05^{\mathrm{a}}$ & $3.26 \pm 0.08^{\mathrm{a}}$ \\
Gizzard \% & $3.17 \pm 0.31$ & $3.39 \pm 0.31$ & $3.69 \pm 0.19$ & $3.22 \pm 0.62$ & $3.40 \pm 0.72$ \\
Kidney \% & $0.49 \pm 0.02$ & $0.44 \pm 0.01$ & $0.53 \pm 0.01$ & $0.61 \pm 0.02$ & $0.38 \pm 0.03$ \\
Spleen \% & $0.14 \pm 0.02$ & $0.14 \pm 0.007$ & $0.13 \pm 0.005$ & $0.14 \pm 0.005$ & $0.15 \pm 0.006$ \\
Pancreas \% & $0.20 \pm 0.01^{\mathrm{a}}$ & $0.36 \pm 0.01^{\mathrm{ab}}$ & $0.41 \pm 0.04^{\mathrm{b}}$ & $0.42 \pm 0.02^{\mathrm{b}}$ & $0.46 \pm 0.01^{\mathrm{b}}$ \\
\hline
\end{tabular}

a,b: Means in the same row with the same letters are not significantly different $(P \leq 0.05)$.

The achieved improvement in body weight, weight gain and feed efficiency, and consequently in body organs due to the coriander supplementation and attributed to the stimulating effect of their essential oils on the digestive processes. These results are in agreement with those of Hernandez et al., (2004), who reported that the supplementation of the essential oils improved the apparent whole digestive tract and the ileal digestibility of nutrients. Similarly, Ramakrishna et al., (2003) reported that the effectiveness of pancreatic lipase and amylase were increased through the supplementation of essential oils. Also, Platel et al., (2002) demonstrated that coriander seeds enhanced the activities of pancreatic lipase, chymotrypsin and amylase. Similar positive effects were reported by Jamroz and Kamel (2002), who observed that the supplementation of essential oils increased the digestion of protein, cellulose and fat in pigs. The positive effect of dietary coriander seeds on body weight, gain and feed efficiency could be attributed to the increased efficiency of feed utilization and /or altered carcass composition. Similarly, Ather (2000) reported an improved performance in broilers when a poly-herbal premix which containing five herbs was used.

Similar results were observed in recent studies which revealed that essential oils had blocking effects on pathogens in the digestive system (Alcicek et al., 2003), and improved feed intakes, feed conversion ratios and carcass yields (Basset, 2000; Hertrampt, 2001; Williams and Losa, 2001; Tucker, 2002; Alcicek et al., 2003 and Giennenas et al., 2003). The low performance in the $\mathrm{G}_{4}(1.2 \%)$ coriander than the other treatments could be attributed to a higher concentration of the essential oils which might have been toxic to quails (Lee et al., 2004).

Physiological and biochemical parameters of blood plasma :

Data in Table (5) showed that plasma total cholesterol, total lipid were not significantly different than those of the control, although the birds that fed on $0.6 \%$ coriander seeds showed a lesser plasma total lipids than the other groups. Plasma ALT activity showed slight significant differences for quails that fed on coriander seeds than those of the control group especially those fed on $1.2 \%$, although, plasma AST activity showed no significant differences between treatments, but the highest activity was achieved by birds fed $1.2 \%$. Concerning the total plasma protein concentration, no significant differences by the different levels of coriander supplementation when compared with control, but the levels of 0.3 and $0.9 \%$ recorded the highest concentrations. 
Table (5): Effect of coriander supplementation on some blood parameters.

\begin{tabular}{|c|c|c|c|c|c|}
\hline \begin{tabular}{|l} 
\\
Parameters \\
\end{tabular} & $\mathrm{G}_{1}$ & $\mathrm{G}_{2}$ & $\mathrm{G}_{3}$ & $\mathrm{G}_{4}$ & $\mathrm{G}_{5}$ \\
\hline Total Cholesterol (mg/dL) & $118.34 \pm 3.42$ & 116.38 & 8.09 & 117.1 & $117.54 \pm 9.25$ \\
\hline mald & 260.23 & 255.44 & 266.25 & 261.75 & 17 \\
\hline & 51.8 & $48.3 \pm$ & 55.6 & & $5 \mathrm{ab}$ \\
\hline & & & 17. & 6 & 38 \\
\hline dl) & 4.6 & 3.99 & $4.2 \pm$ & $42^{\mathrm{a}}$ & $55^{\mathrm{a}}$ \\
\hline Hen & 0.42 & 0.4 & $0.61 \pm$ & $3^{b}$ & $04^{a}$ \\
\hline$H / L$ ratio\% & $0.47 \pm 0.14^{a}$ & $0.41 \pm 0.02^{a}$ & $0.57 \pm 0.13^{a}$ & $0.55 \pm 0.14^{a}$ & $0.45 \pm 0.03^{a}$ \\
\hline
\end{tabular}

$a, b, c:$ Means in the same row with the same letters are not significantly different $(P \leq 0.05)$.

Hematocrit ratio showed significant differences $(P \leq 0.05)$ between the groups, especially at levels of 0.9 and $1.2 \%$ of coriander supplementation. On the other hand, no significant differences in $\mathrm{H} / \mathrm{L}$ ratio between groups but, 0.9 and $1.2 \%$ of coriander seeds had the highest ratio. These results are in close agreement with the findings of Chithra and Leelamma (1997), who reported that the increase of pancreatic enzyme activities enhanced the hepatic bile acid synthesis and increased the degradation of cholesterol to fecal bile acids and appeared to account for its hypocholesterolemic effect. Also, Nikolaus et al., (1999) reported that the petroselinic acid, from triacylglycerols of coriander oil is extensively incoporated into the lipids of heart and liver and metabolized via B-oxidation and chain elongation for its hypocholesterolemic effect.

\section{Microbiological Traits:}

Table (6) showed the effect of different levels of coriander seeds on the total count and colon bacteria. It could be noticed from this table that birds which were fed on $0.6,0.9$ and $1.2 \%$ of coriander had the lowest counts of bacteria, it is clear that coriander seeds were more effective in inhibiting cecal bacteria in quails as compared to the control group (-8.7: -13\%). Also salmonella was not detected in cecal content of birds fed on coriander, especially at levels of $0.6,0.9$, and $1.2 \%$ levels. So, it had an antigonistic effect against some harmful bacteria in quails. On the other hand, it is well recognized that the functionality of the immunological barriers (regeneration of epithelium, activity of T-and B-lymphocytes) are closely linked with nutrition. Also, the balance of microflora in the intestine is very important for health and the correct functioning of the gastrointestinal tract (GIT).

Table (6) : Effect of Coriander supplementation on bacteria counts.

\begin{tabular}{|c|c|c|c|}
\hline Groups & Total Count & Salmonella & Colon bacteria \\
\hline $\mathrm{G}_{1}$ & $115.17 \times 10^{4 a}$ & $0.0^{a}$ & $40.17 \times 10^{4 a}$ \\
\hline $\mathrm{G}_{2}$ & $256.33 \times 10^{4} b$ & $0.0^{a}$ & $78.17 \times 10^{4} \mathrm{a}$ \\
\hline$G_{3}$ & $296.67 \times 10^{4 b}$ & $0.0^{a}$ & $49.83 \times 10^{4 a}$ \\
\hline $\mathrm{G}_{4}$ & $246.0 \times 10^{4 b}$ & $0.0^{a}$ & $63.67 \times 10^{4} \mathrm{ab}$ \\
\hline $\mathrm{G}_{5}$ & $277.5 \times 10^{4 b}$ & $171.0 \times 10^{2 b}$ & $85.17 \times 10^{4 b}$ \\
\hline
\end{tabular}

a,b: Means in the same column with the same letters are not significantly different $(P \leq 0.05)$. 
The number of microorganisms varies in particular parts of GIT from $10^{8}$ up to $10^{12}$ and strictly depends on $\mathrm{pH}$ value of intestine content and the nutrition of animals (Lan et al., 2005). Besides, coriander has linalool which inhibits the pathogenic microorganism in the digestive system. Delaquis et al., (2002) also reported that essential oils derived from coriander negatively affected gram-positive bacteria and gram-negative bacteria. Similarly, Cabuk et al., (2003) observed that linalool affected E.Coli and Salmonella Typhimurium negatively. It could be clearly expected that controlling the gut microflora can positively influence the performance of birds. Also, Jamroz (2005) reported that the aromatic plants include substances having the most important activities which result in improvement of the endogenous enzymes secretion, stimulation the appetite, digestibility and the nutrients absorption, improvement of the microflora balance, decrease of E. Coli and Clostridium population and stimulation of the Lactobacillus spp. proliferation, intestinal villi layer protection, antibacterial, antiviral and antidiarrheal activity and stimulation of the immune system.

In conclusion, the use of herbs and spices as a source of antioxidants to combat oxidation warrants further attention. Immediate studies should focus on validating the antioxidant capacity of herbs and spices and improved the absorption of nutrients. Also, coriander seeds were linked with better keeping quality of meat. Therefore, the coriander seeds supplentation in birds's diets is highly, recommended to improve the absorption of nutrients beside their protective role against the deleterious effects of certain diseases. However, there's a great need for more esearch to determine the appropriate dosage for different poultry species.

\section{REFERENCES}

A.P.H.A. (1976). American Public Health Association compendium of methods for microbiological examination of foods. Speck, M.L. ed., Washington, D.C. USA.

Alcicek, A.; M. Bozkurt and M. Cabuk (2003). The effect of essential oil combination derived from selected herbs growing wild in Turkey on broiler performance. S. Afr. J. Anim. Sci. 33, 89-94.

Ammar, N.M.; S.Y. AL-Okbi and D.A. Mohamed (1997). Study of the antiinflammatory acivity of some medicinal edible plants growing in Egypt. J. of Islamic Academy of Sci. 10: 4, 113-122.

Ather, M.A.M. (2000). Polyherbal additives proves effective against vertical transmission of IBD. World poult-Elsevier 16, 50-52.

Basilico, M.Z. and J.C. Basilico (1990). Inhibitory effects of some spice essential oils on Aspergillus Ochraceus 3174 growth and ocratoxin A production. Lett. Appl. Microbiol. 29, 238-241.

Bassett, R. (2000). Oreganos positive impact on poultry production. World Poult-Elsevier 16, 31-34.

Cabuk, M; A. Alcicek; M.Bozkurt and N. Imre (2003). Antimicrobial properties of the essential oils isolated from aromatic plants and using possibility as alternative feed additives. II. National Anim. Nutr. Cong. 18-20, 184187. 
Chithra, V. and S. Leelamma (1997). Hypolipidemic effect of coriander seeds (Coriandrum sativum) : mechanism of action. Plant Foods Hum. Nutr. 51, 167-172.

Chithra, V. and S. LeeLamma (1999). Coriandrum Sativum changes the levels of lipid peroxides and activity of antioxidant enzymes in experimental animals. Ind. J. Biochem. Biophys. 36,59-61.

Chithra, V. and S. Leelamma (2000). Coriandrum Sativum : effect on lipid metabolism in 1,2-dimethyl hydrazine induced colon cancer. J. Ethnopharmacol. 71,457-463.

Craig, W.J. (1999). Health- promoting properties of common herbs. Am. J. clin. Nutr. 70, 491-499.

Delaquis, P. J.;K. Stanich; B. Cirard and G. Mazza (2002). Antimicrobial activity of individual and mixed fractions of dill, Cilantro, Coriander and eucalyptus essential oils. Int. J. Food Microbiol. 74, 101-109.

Duncan, D. (1955). Mutttiple ranges and multiple F. test. Biometric, 11:1-42.

Elgayyar, M; F. A. Draughon ; D.A. Golden and J.R. Mount (2001). Antimicrobiol activity of essential oils from plants against selected pathogenic and saprophytic microorganisms. J. Food prot. 64, 10191024.

Giannenas , I.; P. Florou-Paneri ; M. papazahariadou; E. Christaki; N. Botsoglou and A. Spais (2003). Effect of dietary supplementation with oregano essential oil on performance of broilers after experimental infection with Eimeria tenella. Arch. Tierernahr. 57, 99-106.

Goyal, K.C.; Y.K. Sharma and U.K. Misra (1984). Effect of carotenoid isolate from green leaves on the growth and hepatic vitamin A levels of vitamin A deficient chicks. Nutr. Report. Intr. 29(5): 1155-1160.

Gray, A.M. and P.R. Flatt (1999). Insulin-releasing and insulin-like activity of the traditional anti-diabetic plant coriandrum Sativum (coriander). Br. J. Nutr. 81, 203-209.

Hernandez, F.; J. Madrid; V. Garcia; J. Orengo and M.D. Megias (2004). Influence of two plant extract on broiler performance, digestibility, and digestive organ size. Poult. Sci 83, 169-174.

Hertrampt, J.W. (2001). Alternative antibacterial performance promoters. Poult. Int. 40, 50-52.

Hossein, H. and M. Mohammad (2000). Anti-convulsant effects of coriandrum Sativum L. seed extracts in mice. Arch. Int. Med 3,182-184.

Hunsaker, W.G. (1969). Sex differences in the percentage of plasma trapped in cell volume determination on avian blood. Poult. Sci. 48, 37.

Jamroz, D. (2005). Nutritional factors Supporting the immune response in animals. Krmiva, Zagreb 4:207-219.

Jamroz, D. and C. Kamel (2002). Plant extracts enhance broiler performance. In non ruminant nutrition: Antimicrobial agents and plant extracts on immunity, health and performance. J. Anim. Sci. 80 (E.Supp1. 1), 41.

Lan, Y. ; M.W.A. Versteegen; S. Tamminga and B.A. Williams (2005). The role of the commensal gut microbial community in broiler chickens. World's Poult. Sci. 61-95-104. 


\section{Gamal EI-Dien, Hala M. et al.}

Langhout, P. (2000). New additives for broiler chickens. World Poult-Elsevier. $16,22-27$.

Miura, K.; H. Kikuzaki N. Nakatani (2002). Antioxidant activity of chemical components from sage (Salvia officinalis L.) and thyme (Thymus Vulgaris L.) measured by the oil stability index method. J. Agric. Food Chem. 50, 1845-1851.

Nikolaus, W.; S. Stefanie; K. Erika and D.M. Kumar (1999). Adipose tissue triacylglycerols of rats are modulated differently by dietary isomeric octadecenoic acids from coriander oil and high oleic sunflower oil. J. of Nutr. 129: 2206-2211.

NRC " National Research Council " (1994). Nutrient requirement of poultry, National Academy press, Washington, D. C. USA.

Oxoid, M. (1992). The Oxoid manual of culture media and other laboratory services, $5^{\text {th }}$ edition, Basingstock: Oxioid, $\mathrm{Hd}$.

Platel , K.; A. Rao; G. Saraswathi and K. Srinivasank (2002). Digestive stimulant action of three Indian spice mixes in experimental rats. Nahrung, 46 (6), 394-398.

Ramakrishna, R.P.; K. Platel and K. Srinivasan (2003). In vitro influence of species and spice-active principles on digestive enzymes of rat Pancreas and small intestine. Nahruny 47, 408-412.

Refai, M.K. (1979). Manuals of food quality control (4-microbiological analysis). Food and Agriculture Organization of United Nations Rome.

Schwarz., S.; C. Kehrenberg and T.R. Walsh (2001). Use of antimicrobial agents in veterinary medicine and food animal production. Int. J. Antimicro. Agents 17, 431-437.

Singh, G.; I. P. Kapoor; S. K. Pandey ; U.K. Singh and R.K. Singh (2002). Studies on essential oils : part 10; antibacterial activity of volatile oils of some spices. Phytother. Res. 16, 680-682.

SPSS (1997). SPSS User's Guide Statistics version 8. Copy right SPSS Inc., USA, Washington, D.C. USA.

Swanston-Flatt, S.K.; C. Day; C.J. Bailey and P.R. Flatt (1990). Traditional plant for diabetes. Studies in normal and Streptozotocin diabetic mice. Diabetologia 33,462-464.

Tucker, L. (2002). Botanical broilers: Plant extracts to maintain Poultry Performance. Feed Int. 23,26-29.

Valero, M. and M.C. Salmeron (2003). Antibacterial activity of 11 essential oils against Bacillus Cereus in tyndallized Carrot broth. Int. J. Food Microbiol. 85, 73-81.

Williams, P. and R. Losa (2001). The use of essential oils and their compounds in poultry nutrition. World poult-Elsevier 17, 14-15. 
قدرة بذور الكزبرة على تعديل بعض الاستجابات الفسيولوجية والميكروبية والأداء

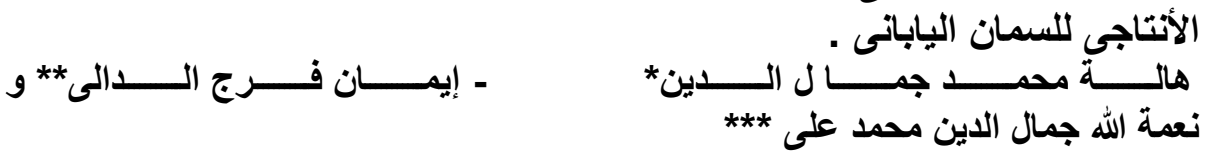

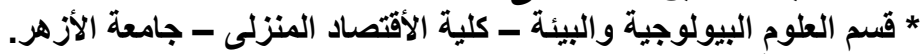

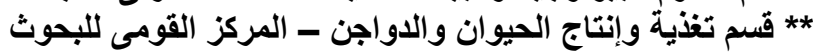

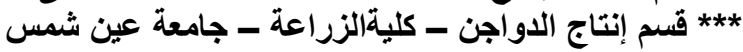

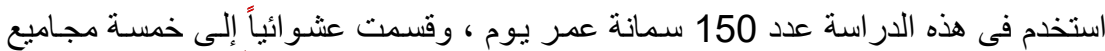

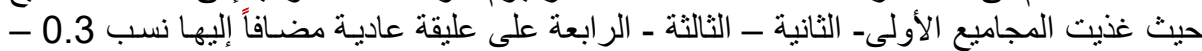

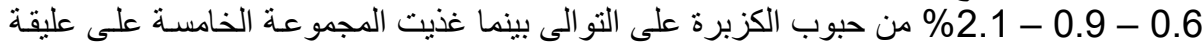

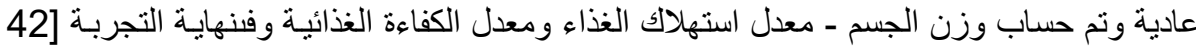

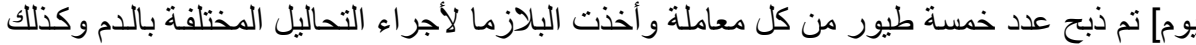

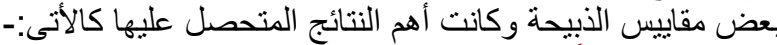

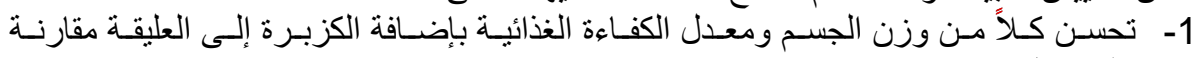

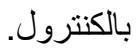

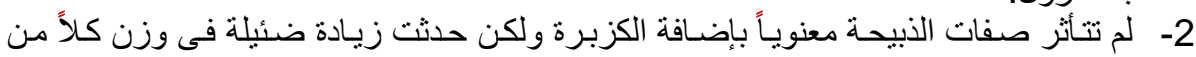

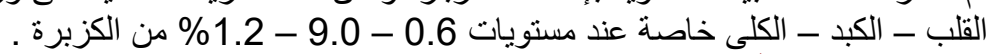

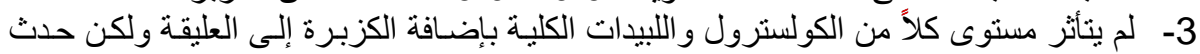

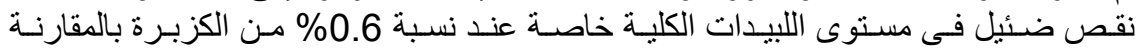

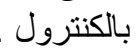
4- تأثر نشاط أنزيم ALT بإضافة الكزبرة مقارنة بالكنترول ، بينما لم يتأثر مستوى نشاط أنزيم . AST 5- لم يتأثر مستوى كلاً من تركيز البروتين فيالبلازمـا ونسبة كرات الدم H/L بإضـافة الكزبرة

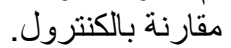
6- تأثرت نسبة المكونات الخلوية بإضافة الكزبرة إلى العليقة مقارنة بالكنتورل خاصـة عند نسبة \% 1.2-0.9 7- قلت أعداد البكتريا فى أمعاء الطيور التى غذيت على نسبة 0.6- 9.0 - 1.2 \% من الكزبرة

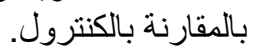

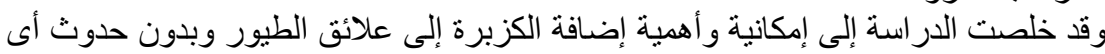

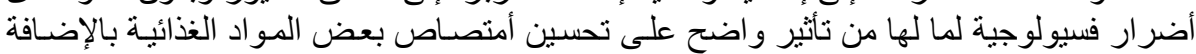

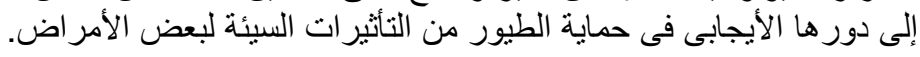

